\title{
Exploration of Zhuozhou's Sustainable Development of the Commerce under the Globalization of the Economy
}

\author{
Zhiguang Wu, Ning Wang, Xuefei Liu \\ Urban and rural planning, \\ Agricultural University of Hebei, \\ Baoding, Heibei, China
}

\begin{abstract}
Since the reform and opening up policy, China's commercial development has made an unprecedented achievement both in speed and in scale in recent years, thus it becomes a dazzling light in the world's economic development. However, in the construction of commercial outlets in recent years, there are some phenomenons such as layout of the chaos, the same function of the formats, business facilities redundant construction, resources waste, and excessive competition because of a lack of unified planning, which will have a negative impact to the sustainable development of commercial economy and prosperity of our country. Under the background of economic globalization, this article makes an exploration about Zhuozhou's business sustainable development in the perspective of the trend of global commerce development field of vision, which will guide the practice of the commercial development of our country in a new scientific concept of development strategy and will ensure our business developing safe and healthy in the fierce international competition.
\end{abstract}

Keywords-economic globalization; sustainable development; business

\section{I.THE COMMERCIAL DEVELOPMENT OF ECONOMIC GLOBALIZATION}

Economic globalization is one of the important characteristics of contemporary world economy, which is a form of human development and progress, and it is also the important trend of the world economy. If we want to keep a certain position and obtain further development in the future world economic landscape, we can only seize the opportunity to face the challenge and integrated into the system of the economic globalization actively.

Looked from the development trend of global commerce, international operation, the structural transformation of the formats, the rise of e-commerce and modern logistics have become a commercial and trade circulation industry development trend and the globalization, scale and chaining of trade circulation enterprises are growing in strength.

\section{THE PARSING OF ECONOMIC DEVELOPMENT CONDITIONS OF ZHUOZHOU CITY}

Zhuozhou City is located in the confluence of Beijing, Tianjin, and Hebei, it is the core of Beijing-Tianjin-Hebei metropolitan circle, and it is also the important satellite city of "New District in the south of Beijing city."

\section{A. Strength}

Zhuozhou has 2,300 years of history, which has unique historical and cultural resources such as "Day of the first states," "The three kingdoms culture," "Lu's culture," "LiXue culture," "The yi culture," and so on.

Zhuozhou's level of economic development in Hebei province is belonged to the upper level. Zhuozhou has occupied the advantage of multiple regional economic development, and it has an economic development advantage of long-term development, rapid development, steady development by the rising of "Bohai triangle" and the rapid development of regional economy of the BeijingTianjin-Hebei region.

\section{B. Weakness}

Zhuozhou has a large demand for social consumption, we can learn that Zhuozhou's GDP declines since 2012 from the date. It is because that there is lack of strength, high level and influential enterprise groups and industry cluster, which caused the city insufficient of various advantage transformation. The city cannot rely on the real estate only.

\section{Opportunities}

Zhuozhou, as the south of Beijing, combined with Beijing commercial market to support the regional commodity distribution center, and to progress the commodity circulation actively, and to perfect the commercial function of Zhuozhou with the help of the close geopolitical relations with Beijing, as well as the historical opportunity of the Beijing-Tianjin-Hebei integration development.

Zhuozhou, as the south of Beijing, combined with Beijing commercial market to support the regional commodity distribution center, and to progress the commodity circulation actively, and to perfect the commercial function of Zhuozhou with the help of the close geopolitical relations with Beijing, as well as the historical opportunity of the Beijing-Tianjin-Hebei integration development.

\section{Challenges}

Beijing is an international city, which has a big city scale, a lot of floating population and a big scale of commercial consumer market. How to make use of the traffic docking of Zhuozhou and Beijing, and make Beijing provide broad market space for Zhuozhou's business resources development and utilization, which is a 
big challenge, is also another round of new challenges after Zhuozhou real estate development.

\section{THE SUSTAINABLE DEVELOPMENT OF ZHUOZHOU'S COMMERCIAL UNDER THE BACKGROUND OF ECONOMIC GLOBALIZATION}

The commercial economy as the medium carrier organization of commodity circulation appears the function of connection between production and consumption in the development of market economy increasingly, which plays an important role in a virtuous cycle in promoting the national economy in the modern economic life [1]. Therefore, we must make the business sustainable development as the core in Zhuozhou commercial network planning, and optimize the commerce to keep pace with the times for Zhuozhou business development.

\section{A. Commercial network planning of Zhuozhou}

According to the Zhuozhou's business development goals, we can determine the core consumers, center for consumers, radiation consumers reasonably. And we also can orientate the five aspects of the business planning such as the theme of the concept, forms, formats, space, measures from the perspective of sustainable development.

\section{1) The theme of business planning}

The theme of business planning is defined as such: cultural and commercial interdependence, taste and fashion symbiosis, Zhuozhou and Beijing city could be concerned as the "same city." Zhuozhou has a long history of culture. We must improve the grade of the city and develop some modern business facilities and a group of commercial service facilities which is high taste, strong characteristics setting leisure, culture and entertainment as a whole.

\section{2) The concept of business planning}

Zhuozhou's business planning concept is made of the capital economic circle, modern business, network business, cultural heritage, landscape business, tourism business, commercial transportation, which will be integrated into commercial network planning in order to meet the economic and social sustainable development of Zhuozhou.

3) The positioning of business format

Take new type business format as the principal, modify and improve traditional business format. We must build commercial pattern of "harmonious but different," to prevent the vicious competition of "identical but disharmonious."

4) The positioning of commercial space

We can make the center of the city as the corecentralized layout, namely make the tradition in combina- tion with the modern; Make the high-speed railway as hub in the east-centralized layout, namely make the internationalization in combination with the commercial circulation. Depending on the ancient city in the west-centralized combined decentralized, namely make the history in combination with the culture. Make the decentralized in combination with the centralized in the south, namely make the tradition in combination with the characteristics. Make the new district business center and ecological park as highlight in the north-centralized layout, namely make the modern in combination with the fashion.

5) The positioning of commercial grade

The municipal commercial outlets are based on improving supporting network and building commercial street. The district business is based on building shopping centers. The commerce of the street, town, and township level is based on building convenient supporting network. Table 1 below explains the specific business hierarchy.

\section{$B$. The measures of the sustainable development of Zhuozhou business}

The sustainable development has become a universal way. We need to pass a new development model for institutional innovation, promote the development of commercial economy circularly, facilitate commercial economy to develop in the direction of ecological innovation model, be able to build system of perfect business economic and ecological innovation eventually [2]. Therefore the following measures have been taken.

1) The strategic measure of Zhuozhou business development

(i) The innovation and development strategy: We should set up the concept of innovative business industry, improve the business leading role in national economy and the pulling effect on consumption to economic growth, and create the innovation of the formats of Zhuozhou in different development stages.

(ii) The culture promotes business strategy: We must integrate historical and cultural resources, carry forward the historical and cultural features, change the potential value which subsided three kingdoms culture, LiXue culture, Yi culture into the commercial value to drive the development of market economy for Zhuozhou.

(iii) The ecological green strategy: We should grasp the relationship of green production, green purchasing and green consumption scientifically to come true an ecological commercially viable. And we may think about the relationship between the environmental protection and resource conservation as a business development consideration to facilitate the construction of ecological green business step by step. 
TABLE I. THE SPECIFIC BUSINESS HIERARCHY

\begin{tabular}{|c|c|c|c|c|}
\hline $\begin{array}{l}\text { Commercial } \\
\text { Grade }\end{array}$ & character & Function Orientation & Target Customers & Main Formats Settings \\
\hline Level 1 & $\begin{array}{c}\text { Municipal } \\
\text { business center }\end{array}$ & $\begin{array}{l}\text { Shopping, cultural entertain- } \\
\text { ment and leisure, tourism } \\
\text { combined with financial and } \\
\text { business }\end{array}$ & $\begin{array}{l}\text { Make services for urban } \\
\text { and migrant workers }\end{array}$ & $\begin{array}{l}\text { Large shopping centers, convenience stores, department } \\
\text { stores, specialty store, discount stores, warehouse club } \\
\text { stores, furniture building materials stores, cultural } \\
\text { entertainment, catering, factory direct sale center }\end{array}$ \\
\hline Level 2 & $\begin{array}{c}\text { District } \\
\text { business center }\end{array}$ & $\begin{array}{l}\text { Shopping, Cultural entertain- } \\
\text { ment, leisure }\end{array}$ & $\begin{array}{l}\text { Make services for this } \\
\text { area and migrant workers }\end{array}$ & $\begin{array}{l}\text { Large-scale comprehensive supermarkets, convenience } \\
\text { stores, department stores, specialty store, discount } \\
\text { stores, cultural entertainment, catering culture }\end{array}$ \\
\hline Level 3 & $\begin{array}{l}\text { Community } \\
\text { business center }\end{array}$ & $\begin{array}{l}\text { ensure people's daily life and } \\
\text { provide the necessary service }\end{array}$ & $\begin{array}{l}\text { Make services for the } \\
\text { community and the } \\
\text { surrounding residents }\end{array}$ & $\begin{array}{l}\text { Medium and small supermarkets, convenience stores, } \\
\text { department stores, specialty store, farmers' markets, } \\
\text { restaurants, community shopping center }\end{array}$ \\
\hline & $\begin{array}{l}\text { Town business } \\
\text { center }\end{array}$ & $\begin{array}{l}\text { Provide daily goods supply } \\
\text { and service for the people; }\end{array}$ & $\begin{array}{l}\text { Make services for the } \\
\text { villages and towns and } \\
\text { administrative villages }\end{array}$ & $\begin{array}{l}\text { Medium-sized supermarkets, convenience stores, } \\
\text { restaurants, small commodity market, farmers markets, } \\
\text { agricultural materials supply }\end{array}$ \\
\hline Level 4 & $\begin{array}{c}\text { Village } \\
\text { business center }\end{array}$ & $\begin{array}{l}\text { Provide daily necessities for } \\
\text { the villagers and services for } \\
\text { the villagers expediently; }\end{array}$ & $\begin{array}{l}\text { Make services for the } \\
\text { village residents around } \\
\text { the network }\end{array}$ & Convenience store, grocery stores \\
\hline
\end{tabular}

(iv) The brand characteristic strategy: We should build the business street of Zhuozhou's characteristic culture, promote the business which is the core of the brand as the way of the allocation of resources, build a brand system of sustainable development potential, put on the brand launch and control the similar commercial brand scientifically to create a good environment for business growth, enhance the regional services and the leading role of the living and consumption.

(v) The business and tourism strategy: We must insist on the ethnic cultural tourism as the inner revitalization for promoting business services, coordinate development the ecological tourism, cultural tourism and the modern trade industry, strengthen the combination of business, tourism and culture, drive material consumption by cultural construction, and drive promoting commercial by tourism.

(vi) The format integration strategy: We should insist on making the business integration and the overall layout on the basis of optimized structure, adjust the formats, layout and scale of the large commercial outlets, develop the modern ways of distribution, enhance the ability of circulation service and active radiation, cultivate the consumption hot spots actively, pull the upgrading of consumption structure and prompt Zhuozhou into an international modern service area and an economic ties servicing for Beijing.

2) The specific measures of Zhuozhou's commercial development

(i) Business combination-the sustainable development of the commercial complex.
The main commercial center is based on the original business scale of middle-Fanyang, then we make the function perfect to build the urban business combination of "prosperous territory naturalness" for Zhuozhou. It will be the city's commercial hub and leading, who will become the preferred shopping sites by the strong cohesion, radiation, cohesion and accessibility.

(ii) Modern business center-the sustainable development of modern civilization.

Modern business center is built along the both sides of Juma river in the north of Zhuozhou, which become the association commercial center of Zhuozhou by the beautiful natural landscape and modern landmark buildings. It provides consumers with more modern and fashionable experience, build the theme as "modern and fashion" and achieve the goal of the sustainable development of modern civilization.

(iii) The electronic commerce-the sustainable development of the information era.

When the global economy is changing from industrial era to information era, the rules of economic activity is experiencing the radical change. Therefore we set up the business center which named the theme as "Circulation the road, limitless business domain" rely on commercial land on either side of the high-speed railway station east of Zhuozhou to build Zhuozhou's electronic business district (CBD) as soon as possible, create a leading enterprises network combined entity with e-commerce, provides a perfect electronic commerce environment for the enterprise and the consumers as well as an information base for the sustainable development. 
(iv) The Gulou street - the continuation of regional culture.

Gulou street is the central axis of the ancient city, which has an irreplaceable role and value in the continuation of city history and culture and can embody the ancient city of style and historical characteristics fully. The Zhuozhou's city commercial belt is based on the old city, Gulou street and two Liao-dynasty tower-“"Zhidu temple tower" and "Yunju temple tower" as cultural theme, and it's theme is: "the ancient city of Zhuozhou, humanistic of Gulou tower."

(v) The walk street - the expression of human history.

We establish a walk street in the area of modern business: the righteousness and pedestrian street. The business street being "righteousness" as the theme comes from The Three Kingdoms period. Bei Liu had two close-fitting swords known as the "male and female twin sword". People give the character features to the two swords, one calls "the swords of benevolence," and the other is called "the sword of righteousness." The two swords were put in hometown Zhuozhou after Liu Bei died. Over the years, the two swords turned into a lane, named "righteousness lane.”

\section{PROSPECTS}

Zhuozhou established a unified, open, competitive, and orderly modern circulation system under the condition of economic globalization. We must further improve the economic competitiveness of the city and meet people's growing demands for material, cultural, and living. The objective is expanding consumption, guiding the production and improving the livelihood of the people, and the goal is building the modern circulation network, then it can promote the construction of commercial outlets developing comprehensive, coordinated and sustainable.

\section{REFERENCES}

[1] Gaoliang Cao, Jun Dai, The sustainable development of commercial economy in county in less developed areas-Jiangxi province as an example. On Economic Theory, Beijing, 2009.

[2] Guowen Li, The rethink of the method of cost accounting for longterm equity investment under the new standard. Xi'an, Sanqin Press in Shanxi, Shanxi, 2010. 